\title{
THE ANTIBACTERIAL EVALUATION OF HALICLONA ASSOCIATED BACTERIA AND THE RELATING COMPOUNDS DERIVED FROM THE HOST
}

\author{
TUTIK MURNIASIH*, MASTERIA YUNOVILSA PUTRA, TRI ARYONO HADI
}

Research Center for Oceanography, Indonesian Institute of Sciences, Jl. Pasir Putih No 1 Ancol Timur Jakarta 14430, Indonesia. Email: tutiic_2000@yahoo.com

Received: 27 February 2018, Revised and Accepted: 18 April 2018

\section{ABSTRACT}

Objective: The objective of this study was to investigate the active compounds derived from Haliclona sp. associated bacteria collected from Untung Jawa Island, Jakarta.

Methods: The bacterial isolation, screening of antibacterial activity, purification, and prediction of potential compounds using liquid chromatographymass spectroscopy/mass spectroscopy (LC-MS/MS) as well as 16S rDNA bacterial characterization were conducted.

Results: The potential extract of bacterial strain UJ.17.10-4 showed the highest anti-Gram-positive bacteria. The 16S rDNA gene of this strain had 99\% similarity with the actinobacteria Agromyces tropicus. Chemical separation of supernatant extract yielded 13 potent fractions. Identification of antibacterial compounds contained in active fractions using LC-MS/MS were halistanol sulphate $\mathrm{C}\left([\mathrm{M}+\mathrm{H}]^{+}: 703\right)$, cyclic bis-1,3dialkylpyridinium $\left([\mathrm{M}+\mathrm{H}]^{+}:\right.$213.72). In previous research reported that these compounds were isolated from Haliclona sponge and showed anticancer activity.

Conclusion: This result supported the ideas that $A$. tropicus plays an important role in synthesizing, halistanol sulfate $\mathrm{C}$, haliclorensin, and cyclic bis1,3-dialkylpyridinium metabolite derived from the host.

Keywords: Antibacterial, Active compounds, Haliclona (gellius) sp., Agromyces tropicus.

(c) 2018 The Authors. Published by Innovare Academic Sciences Pvt Ltd. This is an open access article under the CC BY license (http://creativecommons. org/licenses/by/4. 0/) DOI: http://dx.doi.org/10.22159/ajpcr.2018.v11i7.25510

\section{INTRODUCTION}

Halichondrida, Poecilosclerida, and Dictyoceratida are reported producing bioactive compounds [2]. Especially, Haliclona sp. is one of the marine sponges that produce several potential active pharmacological compounds. At least more than 190 metabolites were isolated from this genus. Haliclona (Gellius) sp. was very potential as antimicrobial and anticancer compounds producer such as cyclic bis-1,3-dialkylpyridinium [6], antimultidrugs resistance compound kendariamide [15], antimycobacterial, hydroxyhaliclonacyclamine A [3]. Difficulties in cultivation have become one of the obstacles to develop drug from sponges.

Previous studies reported that there was a collaboration between sponge and associate microorganisms for synthesizing secondary metabolite. Associated microorganism produces secondary metabolism which is structurally related to their host. The most of the therapeutic compounds producers are marine actinomyces and fungi [11]. Some of the therapeutics active compounds derived from callyspongia associated bacteria such as Pseudomonas taiwanese and Lysinibacillus sphaericus were reported very potential actives against pathogenic bacteria, fungi, and Mycobacterium tuberculosis H7Rv strain [20].

Haliclona was one of marine sponges reported the largest associate microorganisms diversity. $\alpha-, \beta-, \gamma-, \delta$-, and $\varepsilon$-Proteobacteria, Cyanobacteria, Planctomycetes, Firmicutes, Acidobacteria, Actinobacteria, Bacteroidetes, Chloroflexi, Fusobacteria, Nitrospirae, and Verrucomicrobia were detected associated with Haliclona (Gellius) [8]. Based on the NRPS and PKS genes, analysis of Haliclona simulans associated microbiota showed that the most producing active compounds are actinobacteria, sulfitobacter, and pseudovibrio [10]. The investigation of secondary metabolite produced by Haliclona associated microorganism was essential to know the true producer of active compound, as well as to find the cultivable source.

Several compounds that first reported derived from higher marine biota, finally consider being produced by the associate microorganism. First, swinholide A was isolated from Theonella swinholide, later confirmed that this compound was produced by the filamentous heterotrophic bacteria. Polybrominated biphenyl ethers antibiotic compound was derived from Dysidea herbacea that was also produced by endosymbiotic cyanobacteria Escillatoria spongeliae $[13,16]$. Several active compounds that originally derived from marine associate microorganism were benzoic acid that derived from Streptomyces cheonanensis VUK-A [19], 2-Mercaptobenzothiazole derived from Micrococcus sp., and a bacterial isolated from Tedania sponge already in synthesize stage [21].

The purpose of this research was to find the cultivable resource of active compounds as well as to study the related active compounds derived from Haliclona and its associated microorganisms.

\section{METHODS}

A voucher of Haliclona sp., used in this study was collected from the Seribu Island using scuba diving, in June 2014, at the location S. $05^{\circ} 58.422^{\prime}$; E. $106^{\circ} 42.189$. The solvent used for extraction and fractionation were ethyl acetate (Merck), methanol (Merck), acetone (Merck), and n-hexane (Merck). Microorganism media for bacterial isolation were $10 \%$ SYP that contained $0.5 \mathrm{~g}$ peptone, $0.1 \mathrm{~g}$ yeast extract, and $16 \mathrm{~g}$ agar in $1 \mathrm{~L}$ seawater.

\section{Bacterial isolation and antibacterial analysis}

Approximately $1 \mathrm{~cm}^{3}$ square sponge slices were washed using sea water sterile and immersed in $10 \mathrm{~mL}$ sterile sea water. The dilution was adjusted for 1:10, 1:100, 1:1000, and 1:10,000. About $100 \mu \mathrm{L}$ sample solution in each concentration $\left(10^{-1}-10^{-4}\right)$ was dropped in marine agar media. About 1-2 weeks of incubation, the appearing bacterial colony was counted and isolated until obtained single colony.

All of the isolated strains were cultured on $10 \mathrm{~mL}$ of $10 \%$ marine broth and incubated during $72 \mathrm{~h}$ in a shaker incubator at $28^{\circ} \mathrm{C}, 100 \mathrm{rpm}$. After harvesting, the bacterial solution was centrifuged $\left(6000 \mathrm{rpm}, 4^{\circ} \mathrm{C}\right.$, 
$15 \mathrm{~min}$ ) and extracted using organic solvent ethyl acetate for supernatant and acetone for the pellet. All of the extracts were tested for antibacterial activity against Gram-positive bacteria Staphylococcus aureus (Sa) and Bacillus subtilis (Bs) using agar diffusion method [1]. About $20 \mu \mathrm{L}$ of the sample that contained $100 \mu \mathrm{g}$ of the bacterial extract was dropped on paper disk and laid on Mueller-Hinton Agar media after bacterial inoculation. Approximately $10 \mu \mathrm{g}$ of ampicillin was used for positive control and the organic solvent for negative control. After overnight incubation, the zone of bacterial growth inhibition was measured.

\section{Characterization of potent bacterial extract}

The single isolated colony of the potent antibacterial strain was characterized using a molecular method by $16 \mathrm{~S}$ rDNA sequencing. The amino acid pattern compared to the existing online database using BLAST method. The molecular analysis was done in INACC Lab. Research Center for Biology Indonesian Institute of Sciences.

Semi-large fermentation and chemical separation of the potent antibacterial fraction

The potent of bacterial strain UJ $17.10^{-4}$ was cultured in $15 \mathrm{~L}$ of $100 \%$ SYP broth medium in a shaker incubator at $100 \mathrm{rpm}, 28^{\circ} \mathrm{C}$. Harvesting of bacterial broth was done after $72 \mathrm{~h}$ incubation. The bacterial broth was centrifuged at $6000 \mathrm{rpm}$ at $4^{\circ} \mathrm{C}$ for $15 \mathrm{~min}$. The supernatant and pellet were separated and extracted using the organic solvent. The supernatant was partitioned using ethyl acetate $(1 / 1)$, while pellet was using methanol.

After evaporation, both of extracts were assayed against Staphylococcus aureus (Sa) and Bs. The highest zone inhibition among both of extracts was continued for open column chromatography separation.

The supernatant extract was chromatographed using silica gel G (230400 mesh) and eluted with n-hexane/ethyl acetate gradient.

Each fraction was grouped base on the similarity of thin-layer chromatography spot. All of the collected fractions were evaluated for antibacterial activity.

\section{Secondary metabolite analysis}

Secondary metabolite analysis of potent fraction was done using liquid chromatography-mass spectroscopy/mass spectroscopy (LC-MS/MS) chromatography. The solvent used for LC-MS/MS was the methanolwater gradient, flow $0.2 \mathrm{~mL}$, column temperature: $40^{\circ} \mathrm{C}$, and max pressure 300 Bat. Analysis of LC-MS was done at the Jakarta Medical Laboratory.

\section{RESULTS AND DISCUSSION}

Isolation of Haliclona's associated bacterial using direct plating resulted in exactly 31 strains. The evaluation of antibacterial against Gram- positive Sa, in general, showed that the most of bacterial extracts have diameter inhibition at the range of 10-15 mm. Fig. 1 was described the recapitulation of antibacterial evaluation of all of the isolated strains.

The supernatant extracts were moderately active against Sa, about 95.3\% of them showed diameter inhibition (di) in a range of 10-15 mm. Approximately $61.2 \%$ of pellet extracts showed weak activity against Sa with diameter inhibition lower than $10 \mathrm{~mm}$. The supernatant extracts showed more susceptible to Sa than pellet extracts. The activity of supernatant and pellet extracts against Bs seems to be equal, with the total active strains inhibition zone around $10-15 \mathrm{~mm}$, was $61 \%$ and weak activity with inhibition zone $<10 \mathrm{~mm}$ was $38.7 \%$

One of the potent extracts was showed by strain UJ $17.10^{-4} .11$, and it was active against Sa (di: $15 \mathrm{~mm}$ ) and Bs (di: $10.7 \mathrm{~mm}$ ). Isolated strain UJ 17.10 $0^{-4} .11$ was selected for further investigation. Sequencing of $16 \mathrm{~S}$ rDNA for UJ $17.10^{-4} .11$ indicated $99.9 \%$ similar to Agromyces tropicus.

\section{Separation of the potent fraction}

About $2.0434 \mathrm{~g}$ of supernatant extracts was obtained from $15 \mathrm{~L}$ fermentation broth. Separation of this extract was done using silica gel column chromatography and n-hexane-ethyl acetate eluent. This separation resulted in 13 fractions; the antibacterial potency was described in Table 1.

Table 1: The antibacterial assay of $A$. tropicus fractions

\begin{tabular}{lll}
\hline Sample $(50 \mu \mathrm{g})$ & \multicolumn{2}{c}{ Diameter inhibition $(\mathbf{m m})$ against } \\
\cline { 2 - 3 } & Staphylococcus aureus & Bacillus subtilis \\
\hline Ampicillin 10 $\boldsymbol{\mu g}$ & 33.50 & 22.05 \\
Supernatant extract & 8.34 & 20.78 \\
Pellet extract & 6.40 & 14.88 \\
Fraction 1 & 13.40 & 21.70 \\
Fraction 2 & 7.88 & 19.08 \\
Fraction3 & 14.55 & 21.43 \\
Fraction 4 & 8.85 & 18.00 \\
Fraction 5 & 12.93 & 21.48 \\
Fraction 6 & 9.15 & 13.70 \\
Fraction 7 & 8.25 & 17.85 \\
Fraction 8 & 5.15 & 18.45 \\
Fraction 9 & 5.88 & 14.10 \\
Fraction 10 & 4.90 & 15.68 \\
Fraction 11 & 9.13 & 16.33 \\
Fraction 12 & 11.35 & 18.25 \\
Fraction 13 & 7.70 & 19.53 \\
\hline
\end{tabular}

A. tropicus: Agromyces tropicus

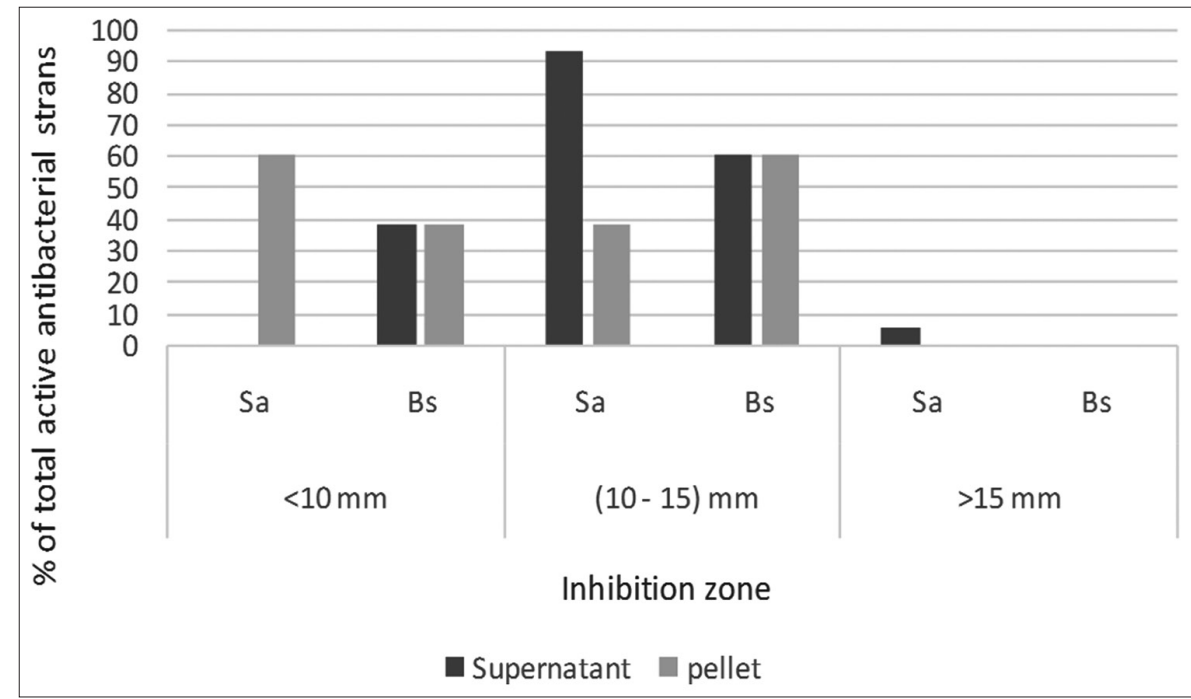

Fig. 1: The potency of bacterial extracts against Staphylococcus aureus and Bacillus subtilis 
Almost all of the fractions were very potent against Bs with the diameter inhibition more than $14.10 \mathrm{~mm}$. The potent fraction against Sa was fraction $1,3,5$, and 12 . These fractions were analyzed for the secondary metabolite.

\section{The result of LC-MS/MS analysis}

The LC-MS/MS analysis of fraction 3 indicated the peaks at retention time 3.66, 4.68, 5.88, 6.73, 14.40, 15.59, 16.27, and $18.65 \mathrm{~min}$. The molecular weight respective to those retention time was 860.61, 449.42, $1371.44,1833.32,1957.93,936.00,1187.01$, and $701.14 \mathrm{~g} / \mathrm{mol}$. The major compound appeared at retention time $4.68 \mathrm{~min}$. The retention time, molecular weight, and predicted compounds are listed in Table 2.

The LC-MS/MS data in Table 2 showed that several compounds contained in the potential fraction of A. tropicus were halistanol sulfate $\mathrm{C}$, triacylglycerol, cyclic bis-1,3-dialkylpyridinium, haliclorensin, chlorothiazide, lysergide, and L-saccharopine.

\section{DISCUSSION}

The potency of bacteria isolated from Haliclona sp. indicated that the most strain has moderate anti-Gram-positive bacteria with the diameter inhibition around $10-15 \mathrm{~mm}$ at the concentration extract was $100 \mu \mathrm{g} / 20 \mu \mathrm{L}$

The supernatant extract of the most bacterial strain showed stronger active against anti-Gram-positive bacterial than pellet extracts. Those data informed that the secondary metabolites were excreted out from the cell or extracellular. The maintenance of membrane cell was essential for bacteria, especially under the stressful condition such as high pressure, nutrient starvation, and high salinity in the marine environment. The bacterial response to environment adaptive will change in metabolite composition such as protein, sterol, hopanoid, carotenoid, and mostly changing in membrane composition $[7,14]$.
This statement supported the ideas that the production of secondary metabolite in bacterial occurred in the membrane cell.

LC-MS/MS spectrum at $[\mathrm{M}-\mathrm{Na}]^{+}: 703$ confirmed that the potential active compound derived from fraction 1 was halistanol sulfate C. Previous study reported that this anti-HSV-1compound was isolated from marine sponge Petromica citrina (Demospongiae) [4], Haliclona sp. [4], Epipolaris sp. [17], and Petromica ciocalyptoides [5].

Compound indicating in the most active antibacterial activity of faction 3 was cyclic bis-1,3-dialkylpyridinium with $[\mathrm{M}+\mathrm{H}]^{+}: 449.992 \mathrm{~m} / \mathrm{z}$. Cyclic bis-1,3-dialkylpyridinium was compound possess cytotoxic and antimicrobial that isolated from Haliclona sp. [6]. The bis-1,3dialkylpyridinium carbon skeletons were variety found contained in Haliclona sp. [9].

The other alkaloid haliclorensin was found in fraction $4[\mathrm{M}+\mathrm{H}]^{+}: 213.72$. The first time, this compound was isolated from Haliclona sp. [10]. The revised structure was reported by Koren et al. (1998) [22]. This alkaloid was cytotoxic with the LD value of $502.1 \mathrm{mM}$ [10].

\section{CONCLUSION}

Considering the result and discussion indicated that marine Actinomyces A. tropicus isolated from Haliclona's sp. collected from Untung Jawa contained several active compounds that previously isolated from the marine sponge Haliclona sp. This finding has supported the ideas that associate microorganisms play a role in producing secondary metabolite.

\section{ACKNOWLEDGMENT}

We are appreciated to RISTEK DIKTI for financial support through INSINAS program (grant no 034/BAP/RPL-LIPI/INSINAS/VIII/2017)

Table 2: The LC-MS/MS data and estimated compounds contained in the potential fractions

\begin{tabular}{|c|c|c|c|}
\hline Fraction no & Retention time (min) & The molecular weight $(\mathrm{m} / \mathrm{z})$ & Possibility compounds \\
\hline \multirow[t]{3}{*}{1} & 1.45 & 1495.40 & $\mathrm{Ni}$ \\
\hline & 20.87 & 703.00 & Halistanol sulfate C [7] \\
\hline & 22.23 & 701.07 & $\mathrm{Ni}$ \\
\hline \multirow[t]{4}{*}{2} & 1.45 & 1743.71 & $\mathrm{Ni}$ \\
\hline & 18.66 & 1124.93 & $\mathrm{Ni}$ \\
\hline & 20.87 & 1967.64 & $\mathrm{Ni}$ \\
\hline & 21.72 & 700.88 & $\mathrm{Ni}$ \\
\hline \multirow{7}{*}{3} & 4.68 & 449.42 & $\begin{array}{l}\text { Cyclic bis-1,3-dialkylpyridinium/ } \\
\text { glycochenodeoxycholate [6] }\end{array}$ \\
\hline & 5.88 & 1371.44 & $\mathrm{Ni}$ \\
\hline & 6.73 & 1833.32 & $\mathrm{Ni}$ \\
\hline & 14.40 & 1957.93 & $\mathrm{Ni}$ \\
\hline & 15.59 & 936.00 & $\mathrm{Ni}$ \\
\hline & 16.27 & 1187.01 & $\mathrm{Ni}$ \\
\hline & 18.65 & 701.14 & $\mathrm{Ni}$ \\
\hline \multirow{3}{*}{4} & 3.49 & 295.93 & Chlorothiazide \\
\hline & 4.34 & 681.77 & $\mathrm{Ni}$ \\
\hline & 4.86 & 323.20 & Lysergide \\
\hline \multirow[t]{4}{*}{5} & 0.94 & 574.73 & $\mathrm{Ni}$ \\
\hline & 2.47 & 1273.60 & $\mathrm{Ni}$ \\
\hline & 3.15 & 906.99 & $\mathrm{Ni}$ \\
\hline & 4.51 & 1366.49 & $\mathrm{Ni}$ \\
\hline \multirow[t]{4}{*}{8} & 1.45 & 276.50 & L-saccharopine [18] \\
\hline & 9.29 & 695.86 & $\mathrm{Ni}$ \\
\hline & 16.27 & 704.10 & $\mathrm{Ni}$ \\
\hline & 20.87 & 1028.44 & $\mathrm{Ni}$ \\
\hline \multirow{4}{*}{13} & 1.45 & 947.97 & $\mathrm{Ni}$ \\
\hline & 17.29 & 927.12 & $\mathrm{Ni}$ \\
\hline & 20.87 & 1157.87 & $\mathrm{Ni}$ \\
\hline & 21.72 & 1207.15 & $\mathrm{Ni}$ \\
\hline
\end{tabular}

LC-MS/MS: Liquid chromatography-mass spectroscopy/mass spectroscopy 


\section{AUTHOR'S CONTRIBUTIONS}

The complete research work and manuscript preparation were done by Tutik Murniasih, MasteriaYunovilsa Putra for structural analysis, and Tri Aryono Hadi for sponge taxonomy and manuscript preparation.

\section{CONFLICTS OF INTEREST}

The authors declared that they have no conflicts of interest regarding the publications of this paper.

\section{REFERENCES}

1. Hudzicki. Kirby-Bauer Disk Diffusion Susceptibility Test Protocol. American Society for Microbiology; 2016. p. 1-23. Available from: http://www.asmscience.org.IP.203.160.128.134.

2. Thomas T, Moitinho-Silva L, Lurgi M, Bjork JR, Easson C, AstudilloGarcia C. Diversity, structure and convergent evolution of the global sponge microbiome. Nat Commun 2016;7:11870.

3. Arai M, Ishida AS, Setiawan A, Kobayashi M. Haliclona cyclamines, tetracyclic alkylpiperidine alkaloids, as anti-dormant mycobacterial substances from a marine sponge of Haliclona sp. Chem Phar Bull 2014;57:1136-8.

4. Bruna AL, Simone PL, Miriam HK, Reginaldo BG, Roberto GS, Regianne UK. Halistanol sulfate A and rodriguesines A and B are antimicrobial and antibiofilm agents against the cariogenic bacterium Streptococcus mutans. Rev Bras Farm 2014;24:651-9.

5. Guimarães TR, Quiroz CG, Rigotto C, Oliveira SQ, Maria TR, Éverson MB. Anti HSV-1 activity of halistanol sulfate and halistanol sulfate C isolated from Brazilian marine sponge Petromica citrina (Demospongiae). Mar Drugs 2013;11:4776-192.

6. Lee Y, Jang KH, Jeon JE, Yang YW, Sim CJ, Oh KB. Cyclic Bis1,3-dialkylpyridiniums from the Sponge Haliclona sp. Mar Drugs 2012;10:2126-37.

7. Carlo CC, Fernandes P. Production of metabolites as bacterial response to the marine environment. Mar Drugs 2010;8:705-27.

8. Sipkema D, Holmer B, Nicholas S, Blanch H. Biological characterisation of Haliclonas (Gellius) sp. Sponge and associated microorganism. Microbiol Ecol 2009;58:903-20.

9. Casapullo A, Pinto OC, Marzocco S, Autore G, Riccio R. 3-Alkylpyridinium alkaloids from the pacific sponge Haliclona $s p$. J Nat Prod 2009;72:301-3.
10. Peng J, Rao KV, Choo YM, Hamann MT. Mazamine Alkaloids. In: Fattorusso E, Scafati T, editor. Modern Alkaloids. Wenham, Italy: Wiley. VCH Verlag GmbH \& Co. KGaA; 2008. p. 198-200.

11. Li Z, He L, Miao X, Cultivable bacterial community from South China Sea sponge as revealed by DGGE fingerprinting and 16S rDNA phylogenetic analysis. Curr Microbiol 2007;55:465-72.

12. Kossuga MH, Lira SP, Nascimento AP, Gambardella MT, Berlinck GS, Torres YR, et al. Isolation and biological activities of secondary metabolites from the sponges Monanchora aff. arbuscula, Aplysina sp. Petromicacio calyptoides and Topsentiao phiraphidies, from the ascidian didemnum ligulum and from the Octocoral carijoariisei. Quim Nova 2007:5:1194-202.

13. Newman DJ, Hill RT, New drugs from marine microbes: The tide is turning. J Ind Microbiol Biotechnol 2006;33:539-44.

14. Satyanarayana T, Johri BN. Microbial Diversity. Current Perspectives and Potential Applications. New Delhi: Khrishan Makhijani for I.K. International Pvt. Ltd;2005. p. 16.

15. Aoki S,Cao L, Matsui K, Rachmat R, Akiyama S, Kobayashi M, et al. A novel peptide reversing P-glycoprotein-mediated multidrug resistance in tumor cells, from a marine sponge of Haliclona sp. Tetrahedron 2004;60:7053-9

16. Hentschel U, Schmid M, Wagner M, Fieseler L, Gernert C, Hacker J. Isolation and phylogenetic analyses of bacteria with antimicrobial activities from the Mediterranean sponges Aplysina aerophoba and Aplysina cavernicula. FEMS Microbiol Ecol 2001;35:305-12.

17. Kanazawa S, Fusetani N, Matsunaga S. Halistanol sulfates A-E. New steroids sulfates, from a marine sponge, Epipolasis sp. Tetrahedron 1992;48:5467-72.

18. CHEBI Database: 16927-L-saccharopine. Available from: http://www. ebi.ac.uk/chebi/searchId.do?chebiId=CHEBI:16927.

19. Naragani K, Mangamuri U, Muvva V, Poda S, Munaganti RK. Antimicrobial potential of Streptomyces cheonanensis VUK-a from mangrove origin. Int J Pharm Pharm Sci 2016;8:53-7.

20. Warad VB, Habbu P, Shastri R. Antimicrobial activity of Callyspongia diffusa (marine sponge) associated endophytic bacterial strains. Int J Pharm Pharm Sci 2017;9:90-6.

21. Ascel A, Zuhair ME, Elham AK, Hiba AM. In vitro microbial time killing curve for newly synthesized amino acetylenic-2-mercaptobenthiazole compound. Int J Pharm Sci 2017;9:125-30.

22. Koren G, Kashman Y, Schleyer M. Haliclorensin. A Novel Alkaloid from the Marine Sponge Haliclona tulearensis. J.Nat.Prod. 1998; 61(2):282-284 